\title{
THE EFFECT OF AUTOCLAVE AND HEAT POLYMERIZATION TECHNIQUES OF INTERNAL ADAPTATION OF ACRYLIC RESINS
}

\section{ISI VE OTOKLAV POLIMMERİZASYONU TEKNİKLERİNİN AKRİLİK REZİNLERİN İNTERNAL ADAPTASYONU ÜZERİNE ETKİSİ}

\author{
Dr. Öğr. Üy. Gonca DESTE GÖKAY* \\ Doç. Dr. Perihan OYAR ${ }^{* * *}$
}

\author{
Doç. Dr. Rukiye DURKAN** \\ Prof. Dr. Ayhan GÜRBÜz****
}

Makale Kodu/Article code: 4254

Makale Gönderilme tarihi; 20.12.2019

Kabul Tarihi: 25.06.2020

DOI : $10.17567 /$ ataunidfd.757302

Gonca Deste Gökay: ORCID ID: 0000-0002-5481-0063

Rukiye Durkan: ORCID ID: 0000-0002-3381-4073

Perihan Oyar: ORCID ID: 0000-0003-3849-9153

Ayhan Gürbüz: ORCID ID: 0000-0003-4066-9609

\section{ABSTRACT}

Aim: Polymerization shrinkage of the resin and distortion of the denture base due to thermal stress is virtually unavoidable during the processing of dentuRes These adverse effects increase the gap between the denture base and underlying mucosa, resulting in an illfitting denture. A variety of methods have been used to evaluate the dimensional changes and/or adaptation accuracy of a denture base. This study compared the adaptation accuracy of maxillary complete denture bases processed using different polymerization techniques; conventional compression-molding technique and autoclave polymerization techniques.

Material and Methods: 42 resin specimens were fabricated from three heat polymerizing denture base acrylics (Meliodent, Paladent, QC-20). The specimens were divided into six groups $(n=7)$. Three of them were polymerized in a conventional water bath and other three were polymerized in autoclave. Internal adaptation was evaluated immediately after finishing by weighting a silicone film between the resin base and the metallic master model (silicone copy technique). Statistical analyses were performed with the SPSS Windows for 15.0. Data were submitted to ANOVA and Tukey's post hoc tests at a significance level of 0.05 .

Results: Comparisons are made among groups submitted to the different polymerization procedure. Interaction of material and polymerization procedure had a statistically significant effect on the final adaptation of the denture bases. When comparing the internal adaptation within each group, all groups of autoclave polymerization had significant decrease of weight of impression materials of mean values (meliodent water bath $2.03 \pm 0.17$, meliodent autoclave $1.29 \pm 0.92$; paladent water bath $2.14 \pm 0.18$, paladent autoclave $1.31 \pm 0.94$; QC-20 water bath 2.20 $0.17, \mathrm{QC}-20$ autoclave $1.45 \pm 0.12$ ). Better internal adaptations were observed when the samples were autoclave polymerized comparing to the conventional heat-polymerized group $(p<0.05)$

Conclusion: Increasing the internal adaptation of resin bases may be achieved by using autoclave polymerization technique, this would markedly contribute to the longevity of denture bases.

Keywords: Denture Bases, Polymerization, Autoclave

öz

Amaç: Akrilik tam protezlerin polimerizasyon aşamasında termal stres ve polimerizasyon büzülmesi nedeniyle protez kaidesinin uyumsuzluğu genellikle kaçınılmazdır. Bu olumsuz etkiler, protez kaidesi ile mukoza arasındaki aralığı artırarak uyumsuz bir protez ile sonuçlanır. Protez kaidesinin boyutsal değișikliklerini ve/veya adaptasyonunu değerlendirmek için çeșitli yöntemler kullanılmaktadır. Bu çalışmada, konvansiyonel ISı ve basınç ile polimerizasyon ve otoklav polimerizasyonu teknikleri kullanılarak bitirilen maksiller tam protez kaidelerinin internal adaptasyonu karşılaştırıımıştır.

Gereç ve Yöntemler: 3 farklı ISI ile polimerize olan akrilik rezin sistemine (Meliodent, Paladent, QC-20) ait 42 adet örnek üretildi. Örnekler $n=7$ olacak şekilde 6 gruba bölündü, grupların üçüne konvansiyonel ısı ile polimerizasyon yöntemi uygulanırken diğer üçüne otoklav polimerizasyonu uygulandı. İnternal adaptasyon, bitimden hemen sonra kaide tabanı ile metalik ana model arasında bir silikon filme ağırlık uygulanması ile silikon kopya yöntemi ile değerlendirildi. İstatistiksel analizler SPSS Windows 15.0 ile yapıldı. Veriler ANOVA ve Tukey'in post hoc testleri ile 0.05 anlamllık düzeyinde değerlendirildi.

Bulgular: Farklı polimerizasyon prosedürlerine tabi tutulan gruplar arasında karşılastırmalar yapılmıștır. Rezin ve polimerizasyon prosedürünün etkileşimi, protez kaidesinin nihai adaptasyonu üzerinde istatistiksel olarak anlamlı bir etkiye sahiptir. Gruplar arası internal adaptasyon karşılaştırılması yapıldığında, otoklav polimerizasyonu uygulanan gruplarda konvansiyonel Isı ile polimerize edilen gruplara

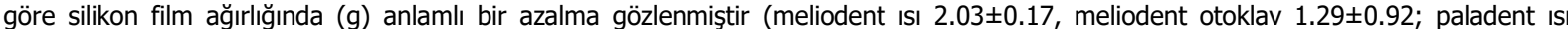
$2.14 \pm 0.18$, paladent otoklav $1.31 \pm 0.94 ;$ QC-20 ISI 2.20 \pm 0.17 , QC-20 otoklav $1.45 \pm 0.12$ ). Örneklerde, konvansiyonel ISI ile polimerize olan gruba kıyasla otoklav ile polimerizasyonda daha iyi internal adaptasyon belirlenmiştir $(p<0.05)$.

Sonuç: Otoklav polimerizasyon yöntemi kullanılarak kaide rezininin internal adaptasyonu arttırılabilir, bu protezin uzun ömürlülüğüne önemli ölçüde katkıda bulunacaktır.

Anahtar kelimeler: Protez Kaideleri, Polimerizasyon, Otoklav

\footnotetext{
*Department of Prosthodontics, Faculty of Dentistry, Bursa Uludağ University, Bursa

* * Department of Prosthodontics, Faculty of Dentistry, Afyonkarahisar Health Science University, Afyonkarahisar

*** Department of Dental Prostheses Technology, Health Services Vocational High School, Hacettepe University, Ankara

**** Department of Prosthodontics, Faculty of Dentistry, Ankara University, Ankara

Kaynakça Bilgisi Gökay GD, Durkan R, Oyar P, Gürbüz A. Isı ve otoklav polimerizasyonu tekniklerinin akrilik rezinlerin internal adaptasyonu üzerine etkisi. Atatürk Üniv Dis Hek Fak Derg 2020; 30: 614-9.

Citation Information: Gökay GD, Durkan $R$, Oyar P, Gurbuz $A$. The effect of autoclave and heat polymerization techniques of internal adaptation of acrylic resins. J Dent Fac Atatürk Uni 2020; 30: 614-9.
} 


\section{INTRODUCTION}

Good complete denture prosthesis should provide esthetics, restore function, and be biocompatible with the supporting and surrounding oral tissues. Polymethylmethacrylate (PMMA) is the most widely used material for the fabrication of denture bases. The advantages of PMMA include excellent esthetic properties, adequate strength, low water sorption, lack of toxicity, facility of repair, and construction by a simple molding and processing technique. ${ }^{1,2}$ PMMA is polymerized by many methods such as heat, light, chemical, microwave energy, and autoclave polymerization. ${ }^{3,4}$ The most frequently used method is water bath processing because it is easy and inexpensive but its main disadvantage is the long processing time. ${ }^{4,5}$ Autoclave was first introduced in 1879 by Charles Chamberland. ${ }^{6}$ Lately autoclave polymerization has been suggested as an alternative to water bath technique. ${ }^{3}$ It is an easymethod and requires less time compared to water bath polymerization technique. ${ }^{4}$

In dentistry, accuracy of fit is particularly useful and important factor in dentures clinical success, and improve the supporting capability of the denture base. It is desirable to increase the internal adaptation of the denture bases to a level as high as possible before it is placed in the mouth. Well-fitted dentures prevent the formation of hyperplastic lesions, chewing efficiency, increase of base strength, and promote patients comfort. ${ }^{7-10}$

Several factors may affect final adaptation of dentures, like the type of the acrylic resin, flask cooling procedure, resorption of the alveolar ridge, water uptake, flexural strength and differences in polymerization techniques. ${ }^{10-14}$

However, dimensonal changes are unavoidably active in every acrylic denture, and at least two types are well known: processing shrinkage and expansion upon immersion in water. ${ }^{8,9}$ Cooling procedure of the flask and polymerization method may affect the processing shrinkage. Expansion of acrylic resin upon immersion in water has been investigated. However, there is little concern about the real effect of such phenomenon on the final adaptation of the denture. Also, it has been shown that the processing method of the material might influence its water uptake and consequent expansion. ${ }^{9}$

Many researchers have attempted to obtain dentures with better adaptation and resistance with many types of polymer or polymerization techniques. $^{13-17}$ These techniques including replacement of the conventional polymerization in hot water bath by alternative polymerization using microwave energy, injection-molding, visible light, dry heat, $¥$ ray-radiation, chemical activators and a newly introduced autoclave polymerization techniques. Autoclave, with high temperature and stream, has been suggested for curing, which has certain advantages. ${ }^{13-25}$

Autoclave polymerization of acrylic resins is easier, practical and sanitary than the conventional technique and may increase the strength of the denture base resin. It has been reported that the temperature and duration of the polymerization affect the transverse strength of heat-polymerized denture base resins. In this case, after polymerization at $60{ }^{\circ} \mathrm{C}$ for about 30 minutes, the temperature is raised to 130 ${ }^{0} \mathrm{C}$ for 20 minutes for final curing. Autoclave machine in which elevated temperature and pressure are used in processing materials. Water is heated in a sealed vessel such as an autoclave, it is possible to heat liquid water to a higher temperature. As the container is heated, the pressure rises due to the constant volume of the container. The boiling point of water is then raised because the amount of energy needed to form steam against the higher pressure is increased. ${ }^{18,19}$ However, to the author's knowledge, no studies have been investigated about the autoclave polymerization techniques for the PMMA denture bases adaptation. At present, it is unknown if the internal adaptation of resin bases is changed by this technique.

Internal adaptation of denture bases indicates the general $3 \mathrm{D}$ distortion of resin base. This can be measured by weighning a film of impression material that reproduces the space between denture base and master model. ${ }^{20}$ For comprehensive evaluation of denture base materials and technical procedures, furher more studies should also assess the internal adaptation of resin bases besides the physical properties.

Therefore, the aim of this study was to evaluate the effect of different polymerization techniques on the internal adaptation of acrylic resin denture bases polymerized by conventional water bath and newly development autoclave techniques are the curing proceduRes

The null hypothesis is that the autoclave polymerization technique of the denture bases may effect the internal adaptation of the denture base acrylic resins were tested. 


\section{MATERIALS AND METHODS}

\section{Preparation of the denture bases}

Three heat polymerizing denture base acrylic resins were selected. Specimen groups, denture base resins brands and compositions are given in Table 1. Polymerization methods used in the study are also shown in Table 2. Total of fourty-two specimens were made with the heat and autoclave-polymerized polymethyl methacrylate resins. The specimens were divided into six groups $(n=7)$. Three of them were polymerized in a conventional water bath and other three were polymerized in autoclave (Ar-El Group SAN, Kosmos, Greece).

Table 1. Some relevant information of the denture base acrylic resins

\begin{tabular}{|c|c|c|c|}
\hline \multirow[t]{2}{*}{ Acrylic resins } & \multirow[t]{2}{*}{ Manufacturers } & \multicolumn{2}{|c|}{ Chemical Compositions } \\
\hline & & Powders & Liquids \\
\hline Meliodent & $\begin{array}{c}\text { Meliodent, Bayer } \\
\text { pental, Berkshire } \\
\text { UK }\end{array}$ & $\begin{array}{l}\text { Methyl methacrylate } \\
\text { Ethyl hexyl acrylate } \\
\mathrm{N} \text {-octyl methacrylate }\end{array}$ & $\begin{array}{l}\text { Methyl methacrylate } \\
\text { Glycol dimethacrylate } \\
\text { Dimethyl p-toluidine }\end{array}$ \\
\hline Paladent & $\begin{array}{c}\text { Heraeus Kulzer } \\
\text { ImbH, Wehrheim } \\
\text { Germany }\end{array}$ & $\begin{array}{l}\text { Polymethylmethacryate } \\
\text { Ethylmethacrytlate, } \\
\text { N-octyl methacrylate }\end{array}$ & $\begin{array}{c}\text { methyl methacrylate, } \\
\text { Glycol dimethacrylate, } \\
\text { Dimethyltouluidine }\end{array}$ \\
\hline QC-20 & $\begin{array}{c}\text { Dentsply } \\
\text { International Inc. } \\
\text { Chicago, USA }\end{array}$ & $\begin{array}{l}\text { Methyl methacrylate } \\
\text { (methyl-n-butyl) co- } \\
\text { polymer, benzoyl } \\
\text { peroxide, atoxic pigment }\end{array}$ & $\begin{array}{c}\text { Methyl methacrylate monomer } \\
\text { ethylene glycol dimethacrylate } \\
\text { EGDMA) as cross-linking agent } \\
\text { terpinolene, N-N dimethyl p- } \\
\text { toluidine, hydroquinone }\end{array}$ \\
\hline
\end{tabular}

Table 2. Summary of detailes of the polymerization methods and curing processes.

\begin{tabular}{|c|c|}
\hline $\begin{array}{c}\text { Polymerization } \\
\text { methods }\end{array}$ & Curing processes \\
\hline $\begin{array}{c}\text { Conventional water bath } \\
\text { polymerization group }\end{array}$ & $\begin{array}{c}\text { Boiling water- } 100^{\circ} \mathrm{C} \text { for } 20 \text { min, Under hydroulic } \\
\text { pressure for } 15 \text { minutes, then water bath } \\
\text { polymerization: } 30 \text { minutes at } 100^{\circ} \mathrm{C}\end{array}$ \\
\hline $\begin{array}{c}\text { Autoclave polymerization } \\
\text { group }\end{array}$ & $\begin{array}{c}15 \text { min under hydroulic pressure, then at } 60^{\circ} \mathrm{C} \text { for } 30 \\
\text { minutes followed by } 130^{\circ} \mathrm{C} \text { for } 20 \text { minutes }\end{array}$ \\
\hline
\end{tabular}

Type III dental stone casts (Gyproc, Prevest Denpro, Jammu, India) were obtained from a vinyl polysiloxane impressions (Elite Double, Zhermack, Rovigo, Italy) of an edentulous Cooper-aluminium maxillary master die containing three pins placed at the incisive papilla and tuberosity regions (Fig. 1). These pins served as indexes for future reposition of the processed denture bases in the master die. Impressions were taken in a custom tray (Light Tray, Ivoclar Vivadent, Schaan, Liechtenstein) with a condensation silicone (Zetaplus, Zhermack, Rovigo, Italy) and casts were poured in type III dental stone. Before pouring the gypsum, three metallic pins were placed in their respective sites in the mould.

The thickness of all denture bases was standardized by using 2-mm plastic sheets and the vaccum system (Plastivac). This study evaluated bases of approximately 2-mm thickness, which represents the average thickness of the central palatal area in the posterior region. The measurement of base misfit in this posterior area using microscopy is higher than in other basal areas.

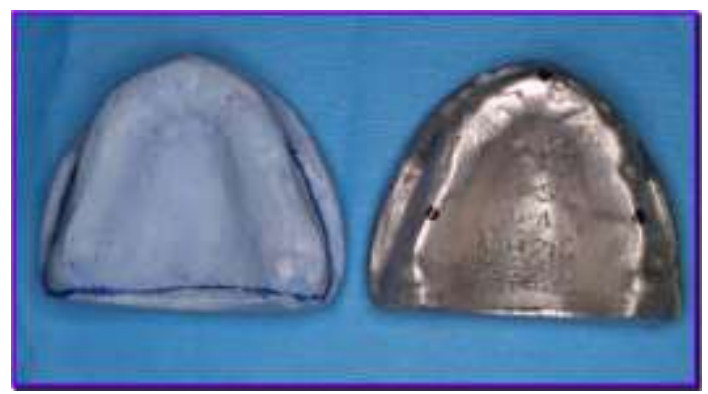

Figure 1. Metallic master model

Conventional water bath polymerized resin groups were manipulated and processed according to the manufacturers instructions. For the autoclave polymerized groups, the specimens were subjected to the processing cycles under $3 \mathrm{~atm}$ pressure, $60^{\circ} \mathrm{C}$ at 30 minutes followed by $130^{\circ} \mathrm{C}$ at 20 minutes. After polymerization, all flasks are allowed to bench cooling for 2 hours.

The bases were deflasked and trimmed until the border limit of the master cast, and stored in $100 \%$ relative humidity environment for 2 hours.

\section{Measurement procedure to evaluate denture adaptation}

Internal adaptation was evaluated immediately after finishing by the test with weighing a silicone film between the resin base and the metallic master model. A standardized portion of flow type vinyl polysiloxane impression material (Express; 3M / ESPE, St. Paul, MN, USA) was prepared and coated the internal surface of each resin base (Fig 2), which was adapted to the master cast under an axial load of 5 $\mathrm{kg}^{7,9}$ The force was applied perpendicular to the center of the specimen strips.

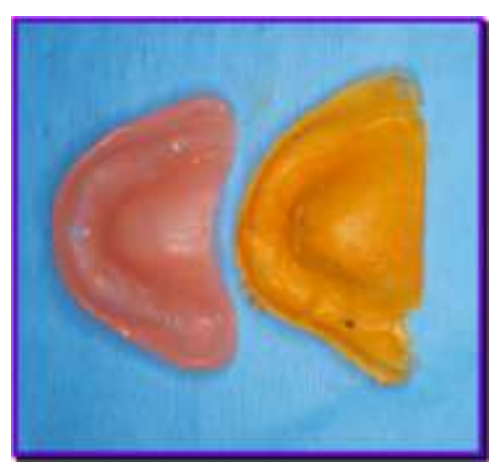

Figure 2. Vinyl polysiloxane impression material 
After the polymerization of the silicone material, the resulting silicon film trimmed at the borderline mark of the master cast and removed from the denture. Then it was weighed using an analytical balance with accuracy of $0.0001 \mathrm{~g}$ (MODEL ag 204, Mettler Toledo, Switzerland) (Fig 3). This procedure was done in dublicate for each specimen, and the average value was recorded to evaluate the internal adaptation of the each specimen.

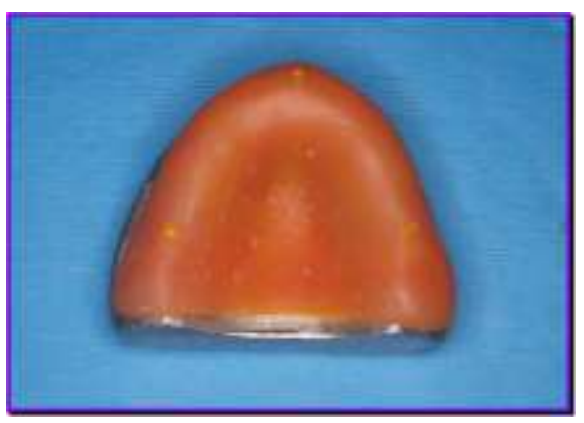

Figure 3. Weighed using an analytical balance with accuracy of $0.0001 \mathrm{~g}$

\section{Ethical approval}

Ethical approval was obtained from the Clinical Research Ethics Committee of Afyonkarahisar Health Science University (decision date: 3.04 .2020 no: 2020/219).

\section{Statistical analysis}

The results were subjected to using SPSS Windows for 15.0 . by means of one-way ANOVA test at a significance level of $5 \%$ to detect variations related to denture base materials and polymerization proceduRes When there was a significant difference among the means, multiple comparisons using Tukey's test were performed $(a=0.05)$.

\section{RESULTS}

Analysis of variance (ANOVA) of the data showed significant differences in weights of impression material $(p<0.05)$ attributable of denture base materials and processing proceduRes Internal adaptation mean values and standard deviations for each experimental group immediately after base finishing Table 3. In relation to adaptation, statistically significant difference was found as a function of polymerization technique $(p<0.05)$. When comparing the internal adaptation within each group, all groups of autoclave polymerization had significant decrease of weight of impression material mean values (meliodent water bath $2.03 \pm 0.17$, meliodent autoclave
$1.29 \pm 0.92$; paladent water bath $2.14 \pm 0.18$, paladent autoclave 1.31 \pm 0.94 ; QC-20 water bath $2.20 \pm 0.17$, QC-20 autoclave $1.45 \pm 0.12$ ).

Table 3. Mean and standard deviation values of the weight of impression material $(\mathrm{g})$ scores of the tested acrylic denture bases

\begin{tabular}{|l|c|c|c|}
\hline $\begin{array}{l}\text { Experimental } \\
\text { groups }\end{array}$ & $\begin{array}{l}\text { Conventional water } \\
\text { bath polymerization }\end{array}$ & $\begin{array}{l}\text { Autoclave } \\
\text { polymerization }\end{array}$ & p values \\
\hline Meliodent & $\mathbf{2 . 0 3} \pm \mathbf{0 . 1 7}$ a & $\mathbf{1 . 2 9} \pm \mathbf{0 . 9 2} \mathbf{b}$ & $\mathbf{p}<\mathbf{0 . 0 0 5}$ \\
\hline Paladent & $\mathbf{2 . 1 4} \pm \mathbf{0 . 1 8}$ a & $\mathbf{1 . 3 1} \pm \mathbf{0 . 9 4} \mathbf{b}$ & $\mathbf{p}<\mathbf{0 . 0 0 5}$ \\
\hline QC-20 & $\mathbf{2 . 2 0} \pm \mathbf{0 . 1 7}$ a & $\mathbf{1 . 4 5} \pm \mathbf{0 . 1 2} \mathbf{b}$ & \\
\hline
\end{tabular}

Immediate adaptation: means followed by different letters are statistically different at $a=.005$ ( $95 \%$ confidence interval).

QC-20 water bath was exhibited significantly different and higher internal adaptation values from the QC-20 autoclave, Meliodent autoclave and Paladent autoclave. Significantly different and higher internal adaptation values were also observed between the Meliodent water bath and QC-20 autoclave, Meliodent autoclave, Paladent autoclave $(p<0.05)$.

Paladent water bath had shown significantly increased $(p<0.05)$ internal adaptation scores compared to the QC-20 autoclave, Meliodent autoclave, Paladent autoclave. In general, all acrylic materials which were polymerized in the autoclave exhibited higher internal adaptation scores compared to the water bath groups. It can be concluded that boiling QC-20 in the water might have the highest whereas Meliodent autoclave shown the least internal adaptation values within the limitation of this study $(p<0.05)$.

\section{DISCUSSION}

The hypothesis in this study is that the autoclave polymerization technique effect the internal adaptation of the denture base acrylic resins. The hypothesis was accepted.

The lack of perfect adaptation is distributed along the basal area and may be compensated by the saliva film and mucosa resilience when dentures are in service. However, in adverse clinical conditions for denture retention, such as highly resorbed ridges, very low salivary flow rates, and motor incoordination, optimal adaptation is desirable and autoclave polymerization method may be recommended for the resin evaluated in this study. Further studies with longer evaluation of internal adaptation of denture bases fabricated with different time and degree and 
assessment of the impact of adaptation values on clinical outcomes are warranted. ${ }^{10}$

There is a continuing effort to improve the properties of denture base materials. Curing processes have been modified to improve the physical and mechanical properties of those materials. ${ }^{26}$ Autoclave polymerization curing is suggested as a good alternative method for denture base resins. ${ }^{27}$

Denture bases that were allowed to the different polymerization procedures showed a statistical difference when compared with each other by using a Tukey's procedure for multiple comparison autoclave polymerization for all the acrylic resins showed the lowest mean weight, thus having the best final adaptation. The results of this study for internal adaptation evaluation after experimental polymerization of autoclave treatment showed significant differences as a function of polymerization technique.

Modifications in the composition and structure of denture base resins and the development of different processing techniques aim to improve physical properties and internal adaptations. ${ }^{9}$ However, resin distortion may arise because of the release of internal stresses induced during these pressing and polymerization proceduRes ${ }^{7,19}$

Ganzarolli et al. ${ }^{7}$ reported that the injectionmolded resin showed better internal adaptation compared with the conventional heat-polymerized and the microwave-polymerized resins, particularly after 30 days. The present study showed that, the autoclave polymerized resins had the best internal adaptation.

According to the manufacturer, the polymethyl methacrylate used has cross-linked chaines, which may provide greater dimensional stability. ${ }^{10}$ Acrylic resins should be properly crosslinked and contain a limited amount of residual monomer. This monomer methyl methacrylate has a boiling point of $100.8^{\circ} \mathrm{C}$ at atmospheric pressure. Therefore, during curing the monomer can evaporate and make bubles in the matrix of the resin, causing the formation of poRes These pores weaken the mechanical strength of the material. In order to avoid this, radical initiated polymerization is first carried out at $60^{\circ} \mathrm{C}$ to consume all of the free monomer, then the temperature is raised to about $100^{\circ} \mathrm{C}$ or higher, to crosslink the polymer. ${ }^{23}$

The limitations of present study is that more acrylic resin materials can be used. The effects of autoclave polymerization on mechanical and biological properties of acrylic resins and residual monomer levels can be investigated. Internal adaptation and other properties of acrylic resins can be investigated by performing autoclave polymerization at different durations and pressuRes In addition, the results of the study can be supported by clinical studies.

\section{CONCLUSION}

Within the limitations of this study it can be concluded that increasing internal adaptation of resin base materials may be achieved by using autoclave polymerization technique. Autoclave polymerization can be easily performed in laboratory conditions. Moreover, it can be routinely used in dental practice after physical and biological tests to reveal the effect of autoclave polymerization on denture base resins. This would markedly contribute to the longevity of denture bases.

\section{There is no acknowledgements in this study.}

There is no conflicts of interest in this study.

\section{REFERENCES}

1. Sushma R, Vande AV, Malvika SR, Abhijeet K, Pronob KS. A comparative study of the mechanical properties of clear and pink colored denture base acrylic resins. Ann Afr Med 2018; 17:178-82.

2. Kaplan R, Özçelik B, Gürbüz A. Reinforcing methods of the acrylic resins used for the fabrication of complete dentuRes J Dent Fac Atatürk Uni 2006; 1:70-6.

3. Abdulwahhab SS: High-impact strength acrylic denture base material processed by autoclave. J Prosthodont Res 2013; 57:288-93.

4. Gad MM, Fouda SM, ArRejaie AS, Al-Thobity AM. Comparative effect of different polymerization techniques on the flexural and surface properties of acrylic denture bases. J Prosthodont 2019; 28:458-65.

5. Banerjee R, Banerjee S, Prabhudesai PS, Bhide SV. Influence of theprocessing technique on the flexural fatigue strength of denturebase resins: an in vitro investigation. Indian Dent Assoc 2010; 21:391-5.

6. Chamberland C: Chronological Reference Marks. Paris; Pasteur Institute: 2007. p 1-19.

7. Ganzarolli SM, Mello JAN, Shinkai RS, Del Bel Cury AA. Internal adaptation and some physical properties of methacrylate-based denture base resins polymerized by different techniques. J Biomed Mater Res Part B: Appl Biomater 2007; 82:169-73. 
8. Akaltan F, Batak B, Oguz EI, Orhan K. Comparative analysis of denture base adaptation performance between pour and other conventional fabrication techniques. J Prosthet Dent 2020; 123:183.e1-3.e5.

9. Ganzarolli SM, Rached RN, Garcia RC, Del Bel Cury AA. Effect of cooling procedure on final denture base adaptation. J Oral Rehabil 2002; 29:787-90.

10. Gomes $M^{\prime}$ Broilo JR, Walber LF, Maccari PCA, Shinkai RSA. Adaptation of complete denture bases submitted to chemical polishing. J Appl Oral Sci 2004; 12:322-5.

11. Sartori EA, Schmidt CB, Walber LF, Shinkai RS. Effect of microwave disinfection on denture base adaptation and resin surface roughness. Braz Dent J 2006; 17:195-200.

12. Ono T, Kita S, Nokubi T. Dimensional accuracy of acrylic resin maxillary denture base polymerized by a new injection pressing method. Dent Mater J 2004; 23:348-52.

13. Faot F, Costa MA, Del Bel Cury AA, Rodrigues Garcia RCM. Impact strength and fracture morphology of denture acrylic resins. J Prosthet Dent 2006; 96:367-73.

14. Pfeiffer $P$, An N, Schmage P. Repair strength of hypoallergenic denture base materials. J Prosthet Dent 2008; 100:292-301.

15. Parr GR, Rueggeberg FA. In vitro hardness, water sorption, and resin solubility of laboratory processed and autopolymerized long-term resilient denture liners over one year of water storage. J Prosthet Dent 2002; 88:139-44.

16. Davenport JC. The oral distribution of Candida in denture stomatitis. Br Dent J 1970; 129:151-6.

17. Durkan R, Oyar P. Comparison of mechanical and dynamic mechanical behaviors of different dental resins polymerized by different polymerization techniques. Niger J Clin Pract 2018; 21:1144-9.

18. Craig RC. Prosthetic applications of polymers: Restorative Dental Materials 10th ed, St. Louis; MO Mosby: 1997. p. 500-51.

19. Durkan $R$, Ozel MB, Bağış $B$, Usanmaz $A$. In vitro comparison of autoclave polymerization on the transverse strength of denture base resins. Dent Mater J 2008; 27:640-2.

20. Rodrigues-Garcia RC, Del Bel-Cury AA. Accuracy and porosity of denture bases submitted to two polymerization cycles. Indian J Dent Res 1996; 7:122-6.
21. Azzari MJ, Cortizo MS, Alessandrini JL. Effect of the curing conditions on the properties of an acrylic denture base resin microwavepolymerized. J Dent 2003; 31:463-8.

22. Harrison A, Huggett $R$, Jagger RC. The effect of a cross-linking agent on the abrasion resistance and impact strength of an acrylic resin denture base material. J Dent 1978; 6:299-304.

23. Ozkir SE, Yilmaz B, Unal SM, Culhaoglu A, Kurkcuoglu I. Effect of heat polymerization conditions and microwave on the flexural strength of polymethyl methacrylate. Eur J Dent 2018; 12:116-9.

24. Bayraktar G, Güvener B, Bural C, Uresin Y. Influence of polymerization method, curing process, and length of time of storage in water on the residual methyl methacrylate content in dental acrylic resins. J Biomed Mater Res Part B: Appl Biomater 2006; 76:340-5.

25. Peracini A, Davi LR, Ribeiro NQ, Souza RF, Silva $\mathrm{CH}$, Paranhos HFO. Effect of denture cleaners on physical properties of heat-polymerized acrylic resin. J Prosthodont Res 2010: 54;78-83.

26. Kareem AE. Strength and surface roughness of cross linking acrylic resin processed by different heat curing methods. Iraqi Dent J 2015; 37:13-9.

27. Atihallah AA, Rola WA, Ali NA. Teeth displacement and palatal adaptation of autoclave cured acrylic resin with various palates and investments. J Bagh Coll Dent 2016; 28:1-10.

\section{Sorumlu Yazarın Yazışma Adresi}

Gonca DESTE GÖKAY

Department of Prosthodontics, Faculty of Dentistry, Bursa Uludağ University, Bursa, Turkey

Phone: +905534313040

E-mail: goncadeste@hotmail.com 